\title{
BIULETYN SZADKOWSKI
}

\section{ANEKS I \\ Informacja o czlonkach zespołu redakcyjnego zaangażowanych w publikację „Biuletynu Szadkowskiego” w latach 2001-2020}

Tadeusz Marszal, prof. dr hab., redaktor „Biuletynu Szadkowskiego” od 2001 r.

Tadeusz Marszał ur. 1952 roku w Łodzi. Absolwent IV LO im. E. Sczanieckiej w Łodzi. W 1974 r. ukończył studia ekonomiczne na Wydziale Ekonomiczno-Socjologicznym Uniwersytetu Łódzkiego, 1982 r. otrzymał stopień doktora z zakresu geografii społeczno-ekonomicznej, a w 1990 roku stopień doktora habilitowanego. Tytuł profesora uzyskał w 2002 roku. W latach 1990-1993 prodziekan Wydziału Biologii i Nauk o Ziemi Uniwersytetu Łódzkiego. W 1991 roku objął stanowisko kierownika Zakładu (od 2002 roku Katedry) Zagospodarowania Środowiska i Polityki Przestrzennej. Od 1995 roku kierownik Centrum Badań Europejskiej Polityki Przestrzennej i Rozwoju Lokalnego. W latach 2001-2002 prodziekan a następnie w latach 2008-2016 dziekan Wydziału Nauk Geograficznych UŁ. Od 2016 roku dyrektor Instytutu Zagospodarowania Środowisk i Polityki Przestrzennej UŁ.

Marek Adamczewski, dr hab., członek redakcji w latach 2010-2018

Marek Adamczewski ukończył studia historyczne na Wydziale Filozoficzno-Historycznym Uniwersytetu Łódzkiego w 1987 roku. W 1998 r. uzyskał stopień doktora, a w 2011 r. stopień doktora habilitowanego nauk humanistycznych w zakresie historii. Asystent (1989-1997) i adiunkt (1998-2011) w Zakładzie Nauk Pomocniczych Historii UŁ. Od 2011 r. profesor nadzwyczajny w Katedrze Historii Historiografii i Nauk Pomocniczych Historii UŁ. W latach 2004-2005 członek zespołu przygotowującego projekt ustawy o symbolach państwa i narodu polskiego, powołanego z upoważnienia Prezydenta RP.

Tomasz Figlus, dr, członek redakcji od 2019 roku

Tomasz Figlus ukończył studia geograficzne o specjalizacji geografia polityczna i studia regionalne na Wydziale Nauk Geograficznych Uniwersytetu Łódzkiego w 2007 roku. W 2011 r. uzyskał tytuł zawodowy magistra historii w Katedrze Historii Średniowiecznej Uniwersytetu Łódzkiego, a w 2013 roku stopień naukowy doktora nauk o Ziemi w zakresie geografii. Asystent (w latach 2007-2013) i adiunkt (od 2013) w Katedrze Geografii Politycznej i Studiów Regionalnych na Wydziale Nauk Geograficznych UŁ.

Elżbieta Jarczak, mgr, członek redakcji od 2013 roku

Elżbieta Jarczak ur. w 1962 roku w Szadku. Od 1986 roku związana z bibliotekarstwem. Od 2011 roku dyrektor Miejskiej i Gminnej Biblioteki Publicznej 
w Szadku. Z zamiłowania społecznik. Inicjuje współpracę stowarzyszeń i instytucji kultury na rzecz społeczności szadkowskiej.

Katarzyna Kilian(-Haraszkiewicz), mgr, członek redakcji od 2001 roku

Katarzyna Kilian ur. w 1971 roku w Sieradzu. W 2003 roku ukończyła studia magisterskie na kierunku filologia polska na Wydziale Filologicznym Mazowieckiej Wyższej Szkoły Humanistyczno-Pedagogicznej w Łowiczu. W latach 1992-2019 dyrektor Miejsko-Gminnego Ośrodka Kultury w Szadku. W latach 2009-2012 roku wykładowca Społecznej Akademii Nauk w Łodzi na kierunku kulturoznawstwo. Obecnie główny specjalista ds. projektów promocyjnych w Departamencie Promocji Urzędu Marszałkowskiego w Łodzi.

Sylwia Kowara, mgr, sekretarz redakcji 2008-2013, członek redakcji w latach 2014-2016

Sylwia Kowara ur. w 1982 roku w Łodzi. W 2007 roku uzyskała tytuł zawodowy magistra gospodarki przestrzennej na Wydziale Nauk Geograficznych i Wydziale Zarządzania Uniwersytetu Łódzkiego, broniąc pracę dyplomową wyróżnioną w konkursie Burmistrza Miasta i Gminy Szadek. W latach 2010-2013 asystent naukowo-dydaktyczny w Katedrze Zagospodarowania Środowiska i Polityki Przestrzennej UŁ.

Mariusz Lamprecht, dr, członek redakcji w latach 2004-2009

Mariusz Lamprecht ur. w 1973 roku w Łodzi. W 1999 roku ukończył studia geograficzne na Wydziale Biologii i Nauk o Ziemi Uniwersytetu Łódzkiego. Stopień doktora nauk geograficznych uzyskał w 2010 r. Asystent (2003-2010) i adiunkt (od 2010) w Katedrze (Instytucie od 2016) Zagospodarowania Środowiska i Polityki Przestrzennej UŁ.

Katarzyna Milewska, dr, sekretarz redakcji w latach 2001-2007

Katarzyna Milewska ur. w 1975 roku w Lodzi. W 1999 roku ukończyła studia geograficzne o specjalizacji kształtowanie i ochrona środowiska geograficznego na Wydziale Biologii i Nauk o Ziemi Uniwersytetu Łódzkiego. W 2008 r. otrzymała stopień doktora nauk o Ziemi w zakresie geografii. Asystent (2000-2008) i adiunkt (2008-2016) w Zakładzie (od 2002 roku w Katedrze) Zagospodarowania Środowiska i Polityki Przestrzennej UŁ. W latach 2000-2001 inspektor w Wydziale Gospodarki Przestrzennej, Budownictwa i Komunikacji Łódzkiego Urzędu Wojewódzkiego; od 2017 roku inspektor w Biurze Architekta Miasta Urzędu Miasta Łodzi.

Dorota Stefańska, mgr, członek redakcji od 2001 roku

Dorota Stefańska ur. w 1955 roku w Zelowie. Absolwentka Liceum Ogólnokształcące w Zelowie. Ukończyła studia historyczne na Wydziale Filozoficzno-Historycznym Uniwersytetu Łódzkiego. W latach 1978-2011 na- 
uczyciel historii w Szkole Podstawowej i Gimnazjum w Szadku. Członek Zarządu i Prezes (2007-2012) Towarzystwa Przyjaciół Szadku.

Jarosław Stulczewski, mgr, członek redakcji od 2014 roku

Archiwista, regionalista, publicysta i działacz społeczno-kulturalny. W 2017 r. ukończył studia wyższe (archiwistyka) na Wydziale Nauk Historycznych Uniwersytetu im. Mikołaja Kopernika w Toruniu. Badacz historii regionalnej. Od roku 2013 prezes Towarzystwa Przyjaciół Zduńskiej Woli.

Piotr Szkutnik, dr, członek redakcji od 2003 roku

Piotr Szkutnik ukończył studia historyczne na Wydziale Filozoficzno-Historycznym w 2002 roku. W 2010 roku uzyskał stopień doktora nauk humanistycznych w zakresie historii. Asystent (2003-2020) i adiunkt (od 2010) w Zakładzie Nauk Pomocniczych Historii UŁ. Od 2011 roku adiunkt w Katedrze Historii Historiografii i Nauk Pomocniczych Historii UŁ.

Szymon Wiśniewski, dr, sekretarz redakcji od 2014 roku

Szymon Wiśniewski ur. w 1987 w Łodzi. W 2011 roku uzyskał tytuł zawodowy magistra gospodarki przestrzennej na Wydziale Nauk Geograficznych i Wydziale Zarządzania Uniwersytetu Łódzkiego, a w 2014 roku stopień doktora nauk o Ziemi w zakresie geografii społeczno-ekonomicznej na Wydziale Nauk Geograficznych UŁ. Asystent (2012-2014) i adiunkt (od 2014) w Katedrze (Instytucie od 2016) Zagospodarowania Środowiska i Polityki Przestrzennej UŁ. Od 2016 roku sekretarz Ośrodka Badawczego Europejskiej Polityki Przestrzennej i Rozwoju Lokalnego oraz członek Komisji Geografii Komunikacji Polskiego Towarzystwa Geograficznego.

Beata Woziwoda, dr hab., członek redakcji od 2010 roku

W 1991 roku ukończyła studia biologiczne na Wydziale Biologii i Nauk o Ziemi Uniwersytetu Łódzkiego. W 2001 roku uzyskała stopień doktora, a w 2015 roku doktora habilitowanego nauk biologicznych w dyscyplinie ekologia. Asystent (1998-2002) i adiunkt (od 2002) w Katedrze Botaniki (od 2001 r. w Katedrze Geobotaniki i Ekologii Roślin na Wydziale Biologii i Ochrony Środowiska). Kierownik Zakładu Systematyki i Geografii Roślin w Katedrze Geobotaniki i Ekologii Roślin na Wydziale Biologii i Ochrony Środowiska UŁ. 